(REVIEW ARTICLE)

\title{
Persistent organic compounds in the environment their impact on human health: A review
}

\author{
Bansal Om Prakash * \\ Chemistry Department, D.S. College, Aligarh-202001, India.
}

Publication history: Received on 30 July 2019; revised on 14 August 2019; accepted on 16 August 2019

Article DOI: https://doi.org/10.30574/gscbps.2019.8.2.0145

\begin{abstract}
Globally the organic contaminants are most widespread persistent organic compounds (POPs). The POPs include polycyclic aromatic hydrocarbons (PAHs), polychlorinated di benzo -p-dioxins (PCDDs), polychlorinated dibenzofurans (PCDFs) and polychlorinated biphenyls (PCBs), dioxins, antimicrobials, etc. The PAHs are generated by incomplete combustion of coal, diesel, coal tar pitch, tobacco; volcanic eruption and motor vehicle exhaust, etc.; the polychlorinated biphenyls (PCBs), dibenzo-p-dioxins (PCCDs), polychlorinated dibenzofurans (PCDFs) are introduced in the environment via agricultural applications, industrial waste, household wastes. Major exposure routes to the POPs for humans are via inhalation, ingestion, and dermal contact. These contaminants are deposited in marine, freshwater ecosystem and food chain and have adverse effects on organisms and human health. Some of these chemicals have mutagenic and/or carcinogenic properties. In this review methods of the removal of the PAHs have also been discussed.
\end{abstract}

Keywords: Persistent organic compounds; Polycyclic aromatic hydrocarbons; Environment; Human health; Polychlorinated biphenyls

\section{Introduction}

Persistent organic compounds one of the most widespread organic contaminants of the environment, are those organic compounds which resist chemical, biological and photolysis degradation in the environment. Polycyclic aromatic hydrocarbons (PAHs), polychlorinated dibenzo-p-dioxins (PCDDs), polychlorinated dibenzofurans (PCDFs) and polychlorinated biphenyls (PCBs), DDT, HCH, chlordane, toxaphene (organic pesticides), antimicrobials and dioxins are stable [1] and toxic to human, animals and aquatic flora and fauna. There are 16 PAHs which are generally found in the environment. Most stabling pesticides in the environment are DDT, HCH, aldrin and dieldrin, chlordane endrin, Chlorpyrifos, mirex, heptachlor; stable mycotoxins are Aflatoxin, ochratoxin, Deoxynivalenol, Zearalenone, Fumonisins; Antimicrobials are tetracyclines, Quinolones, Macrolides, Sulfonamides and PCBs, toxaphene, dioxins and furans [2].

Branded or non-branded toys, mouse pads, bathing shoes, bicycle handles, tools, shoes, sport items, car tyres, synthetic turfs, wood preservatives, road building materials, clay pigeons used for shooting exercise contain persistent organic compounds polycyclic aromatic hydrocarbons [3]. The effects of these pollutants also occur at a far distance from the origin place as these compounds are transported by wind, water. Volatile persistent organic pollutants such as $\mathrm{HCH}, \mathrm{HCB}$ are dispersed throughout the world even on Polar Regions. As these compounds persist for long periods and are bio accumulated in environment are passed from one species to another via food chain causing harmful effects to the ecosystem and human health. Though many POPs, such as PCBs, DDT, and dioxins are beneficial in pest and disease control, crop production, and industry, these have several adverse effects on human health, and the

\footnotetext{
${ }^{*}$ Corresponding author

E-mail address: drop1955@gmail.com
} 
environment. The environmental stability of POPs is because of their lipophilic nature, hydrophobicity, and molecular stability. As PAHs are semi volatile they move in between the atmosphere, and the earth's surface. These compounds are present in all the parts of the environment viz., atmosphere, sea water, groundwater, surface water, soils, air, sewage sludge, and sewage water, plants (crops) even in bovine and mother milk [4-6].

DDT which was used since 1940, for agriculture, forests, home, and for prevention of vector born disease malaria, was banned in the USA and other developed countries since 1972 due to its adverse effects. Maximum consumption of DDT was in the year 1970 and approximately 5.5 lakh ton of DDT were used globally. After 1972 as most of the developed countries banned DDT its use decreased since then. Later on developing countries also banned DDT. At Stockholm in 2001; during the "Convention on Persistent Organic Pollutants" it was inferred to recommend reintroducing DDT in Asian and African countries for controlling the vector-borne disease malaria. So, World Health Organization (WHO) in 2006 reintroduced DDT a hazardous substance in Asia and Africa for controlling the vector-borne disease malaria [7]. Because of which the DDT is still used extensively in China, India and other Asian and African countries [7, 8].

\section{Adverse effects of persistent organic compounds}

Dermal contact, inhalation, and ingestion are the major routes of the absorption of PAHs and other persistent organic pollutants by mammals. Plants absorb through roots. The human beings inhale PAHs mainly by breathing ambient and indoor air, smoking cigarettes, tobacco smokes. Crops wheat, lentil and rye also contain PAHs either by synthesis or absorption from air, soil, and water ingestion of such crops by the human is another source of PAHs in human beings. Rain or snow causes the return of PAHs containing dust on the earth.

Some short-term effects of PAHs exposure to human is eye irritation, nausea, skin irritation, vomiting, diarrhoea, and confusion $[9,10]$. The long- term exposure of PAH to human via any source causes DNA mutations, developmental malformations, leukaemia, decreased immune function, cataracts, oxidative stress, asthma like symptoms, reproductive defects, skin, lung, bladder, bone, brain cancer and scrotal [11-13]. A long prenatal exposure of the high concentration of PAHs is associated with lower IQ [14]. Exposure to DDT may cause neurological and immunodeficiency disorder, brain, pancreatic, breast, prostate cancer $[15,16]$. Acetylcholinesterase enzyme activity is also inhibited by DDT [17]. PCBs, PBDEs in the smaller amount can impair the brain development of young ones causing lifelong behavioural impairment. There are also reports of physical and mental development retardation in children who are exposed to POPs. Exposure to PCBs can cause neurological disorder as hyperactivity, reduced memory, attention deficits, and affects immune system. Fish, birds, and mammals in and around the Great Lakes containing POPs show behavioural abnormalities and birth defects. Human whose diets include large amounts of fish, shellfish, or wild foods and sensitive populations with suppressed immune systems are more susceptible to these pollutants.

\section{Sources of polycyclic aromatic hydrocarbons (PAH)}

The sources of PAHs are natural and anthropogenic activities. The PAHs in the environment enters by three processes,

(i) Pyrogenic: Pyrogenic PAHs are produced when organic substances been heated at high temperature in absence or low amount of oxygen; destructive distillation of coal; thermal decomposition of petroleum into smaller aromatic hydrocarbons; incomplete combustion of motor fuel; incomplete combustion of fuel oil in the heating system.

(ii) Petrogenic: Oil spills (oceanic or freshwater), petroleum storage tank leak are some sources of petrogenic PAHs.

(iii) Biological: Biological PAHs are produced because of degradation of vegetative matter, synthesis by plants and bacteria

\subsection{Natural}

Forest and bush fires, waste burning, volcanoes, petroleum seeps, decomposition of vegetative litter fall, erosion of petroleum hydrocarbons containing rocks, hydrothermal processes are the natural sources of PAH [18-21].

\subsection{Anthropogenic activity}

Coal and burning of woods [22], incomplete combustion of oil gas, coal, biomass, garbage, tobacco, charbroiled meat, vehicular exhaust emission, oil exploration (refining), power generation and industrial production, and jet aircraft 
exhausts, roofing tar, sewage sludge and creosote materials are some sources because of anthropogenic activities [2326].

A review of literature denote that globally annually over 6 lakh ton of PAHs are emitted into the atmosphere. China emitted the maximum amount of PAHs followed by India. Wang et al., [27] reported that emission of PAHs in China exceeds 30,000 tons per annum.

\section{Reservoirs of POPs}

Through effluent runoff, wind air, and atmospheric deposition POPs are deposited in both marine and freshwater ecosystem. POPs are strongly bonded with particulate matter sediments act as reservoirs or sinks of POPs. In the living organisms the POPs are accumulated in the body fat and the concentration magnify on moving from one creature to other. During the monsoon season in India PAHs are transported and deposited to soil, grass, snow, and ice, and sediments [28].

The concentration of PAHs in surface water ranged from 12.78-84.65 ug/L [29, 30]. Karyab et al., [31] found that in the drinking water of Tehran the concentration of the PAHs were 18.8 times higher than the acceptable level as proposed by the WHO and the dermal exposure of PAHs via water sources (swimming and bathing in polluted water) was more than water ingestion. Edokpayi et al., [32] reported that concentration of the PAHs in the river water of South Africa ranges from 15.1-16.6 mg/L; while in wastewater treatment plant it was $13.17 \mathrm{mg} / \mathrm{kg}$. In the river sediments of South Africa the concentration of PAHs ranges from 27.1 to $55.9 \mathrm{mg} / \mathrm{kg}$. These results denote that in the South Africa the Concentration of PAHs were more in sediments samples than water samples. The waste water treatment plants were hot spots for PAHs. They also reported that pyrogenic PAHs were more than petrogenic PAHs.

The concentration of the PAHs in the agricultural soils and sediments globally ranges from $1 \mathrm{mg} / \mathrm{kg}$ to $300 \mathrm{~g} / \mathrm{kg}$ based on dry weight [29]. A survey of literature denotes that the concentration of PAHs in the river sediments ranges from $0.3 \mathrm{ng} \mathrm{g}^{-1}$ to $0.3 \mathrm{mg} \mathrm{g}^{-1}$. The maximum concentration was reported in the sediment of Haihe River, China [32] while minimum in the sediment of Evrotas River Greece [33]. The PAHs concentration in the sediment of Gomati river (India) ranges from 5.24 to $3722.87 \mathrm{ng} \mathrm{g}^{-1}$ [34], while the PAHs concentration in water ranged from 12.78-84.65 ug/L [29]. Aly Salem et al., [35] during their analysis for PAHs and aliphatic hydrocarbons from the sediments collected from the Suez Gulf, Aqaba Gulf and the Red Sea proper stations Egypt found that total aliphatic hydrocarbon concentration $\left(\mathrm{C}_{14-}-\mathrm{C}_{32}\right)$ varied from 33.97 to $553.48 \mathrm{ng} / \mathrm{g}$ (mean $174.8 \pm 167.06 \mathrm{ng} / \mathrm{g}$ ), while total PAHs concentrations were between $0.74-456.91 \mathrm{ng} / \mathrm{g}$ (mean $32.94 \mathrm{ng} / \mathrm{g}$ ). In the sediments of Sado estuary the PAHs concentration was up to $7,350 \mathrm{ng} \mathrm{g}^{-1}$ and polychlorinated biphenyls up to $62.2 \mathrm{ng} \mathrm{g}^{-1}$. In the sentinel fish from the Douro River estuary the polychlorinated biphenyls were up to $810.9 \mathrm{ng} \mathrm{g}^{-1}$. The concentration of PAHs in sediments ranged from $0.87-11.23 \mathrm{mg} / \mathrm{kg}$. The accumulation of the PAHs in the soils is due to their strong sorption by soil organic matter and lesser degradation.

Maliszewska-Kordybach et al., [36] reported that PAHs concentration in the Central European agricultural soils ranges from 30 to $4108 \mathrm{ug} / \mathrm{kg}$ while the prevention limit was $1000 \mathrm{ug} / \mathrm{kg}$. Kumar et al., [37] during their studies on the concentration of PAHs and related Carcinogenic Potencies in Roadside Soil within a Developing City of Northern India found that the concentration of PAHs in summer, winter, autumn, and the rainy seasons were 16.53, 4.04, 17.49, and $7.82 \mu \mathrm{g} \mathrm{g}^{-1}$ respectively and the average ratio of a low and high carcinogenic PAHs was found as 1:6, 1:3, 1:7.6, and 1:3.2 respectively. Bortey-Sam et al., [38] studied the concentration of PAHs in the surface soils of Kumasi Metropolis, Ghana and found that total PAHs concentration in the surface soils ranged from 14.78 to $2084 \mathrm{ng} / \mathrm{g}$ dry weight (mean $442.5 \mathrm{ng} / \mathrm{g}$ ). They also reported that Carcinogenic potency of PAHs load was approximately 150 times higher.

Bi et al., [39] during their studies on polycyclic aromatic hydrocarbons in soils from the Central-Himalaya region: Distribution, sources, and risks to humans and wildlife found there is a risk to wildlife and environment of the region because of PAHs beyond permissible limit in the $39 \%$ of the soil samples. The concentration of PAHs in soils ranges from 240 to $330 \mathrm{ng} / \mathrm{g}$ dry weight. The additive cancer risk index values $\left(3.8 \times 10^{-3}-9.2 \times 10^{-1}\right)$ indicates the soil PAHs poses a minimum additional risk of cancer to residents via direct contact and using the potable water. They also found that major source (approximately 85\% ) of PAHs in soils of the Central Himalayas were from pyrogenic origins, out of which $33 \%$ was from combustion of coal, $30 \%$, from unburned petroleum hydrocarbons and $22 \%$, from combustion of biomass.

Wang et al., [40] studied the concentration of PAHs in the semi-arid city of Xi'an in Northwest China and found that total concentration in the urban soil ranged from 390.6 to $10,652.8 \mu \mathrm{g} / \mathrm{kg}$ (mean $2052.6 \mu \mathrm{g} / \mathrm{kg}$ ), which denote heavy 
pollution. The toxic equivalency quantities (TEQs) values ranged in between 21.16 and $1625.78 \mu \mathrm{g} / \mathrm{kg}$ (mean $423.86 \mu \mathrm{g} / \mathrm{kg}$ ) denote a high toxicity potential.

Zhao et al., [41] reported $200 \mathrm{ug} / \mathrm{kg}$ of PAHs in smoked fish meats and $130 \mathrm{ug} / \mathrm{kg}$ in barbecued meat. Mohamed et al., [42] reported that in Egypt, the milk beverages contain $6.07 \mu \mathrm{g} / \mathrm{g}$ of PAHs, while in milk powder it was $8.2 \mu \mathrm{g} / \mathrm{g}$, while the concentration of PAHs in the unsmoked cheese and yogurt were $1.3 \mu \mathrm{g} / \mathrm{g}$.

A review of literature denote that DDT in water ranges from 1 to $5794 \mathrm{ng} / \mathrm{L}$ in China, India and other Asian and African countries [43-46], in soil and river sediments it ranges from $0.0086-1600 \mathrm{mg} / \mathrm{kg}$ [47]. The total concentrations of the PAHs in sediments ranges from $274.06 \mu \mathrm{g} / \mathrm{kg}$ to $2656.65 \mu \mathrm{g} / \mathrm{kg}$, while the total concentrations of the OCPs, PCBs, and PBDEs were $3103.36 \mu \mathrm{g} / \mathrm{kg}, 87.31 \mu \mathrm{g} / \mathrm{kg}$, and $13.88 \mu \mathrm{g} / \mathrm{kg}$, respectively.

\section{Removal of PAHs from environment}

PAHs can be removed from the environment by dry deposition, and wet deposition, and hyper accumulation, and by degradation $[48,49]$.

\subsection{Dry deposition}

Dry deposition means sorption of PAHs on atmospheric particles settled on the earth [50]. Dry deposition of PAHs depends on sorbent particles, temperature, atmospheric conditions.

\subsection{Wet deposition}

Wet deposition means precipitation of sorbed contaminants and dissolution of vapour phase PAHs into precipitate [51]. The studies have showed that sorbed contaminants are more removed by this method than vapour phase PAHs [52], the removal of PAHs from air is more removed in summer and spring than in winter.

\subsection{Hyper accumulation}

Kacalkova and Tlustos [53] during their field studies found that roots of maize (Zea mays L.) and sunflower (Helianthus annuus) can accumulate $1530 \mathrm{ug} / \mathrm{kg}$ of total PCBs and $3.42 \mathrm{mg} / \mathrm{kg}$ of PAHs from the Czech soils. Maize (Zea mays L.), sunflower (Helianthus annuus), polar (Populus nigra) and willow (Salix x smithiana) can also accumulate hexa and hepta chlorobiphenyls and their congeners.

\subsection{Degradation of PAHs}

Degradation of PAHs in the environment occurs via chemical oxidation, biological and photochemical oxidation, leaching, adsorption by soil particles and bioaccumulation.

\subsection{Chemical degradation}

PAHs undergo three types of the reactions' viz., electrophilic substitution, oxidation and reduction. The aromatic characters of the PAHs are destroyed by oxidation and reduction reactions. PAHs in soils are degraded into a mixture of ketones, aldehydes, phenols, carboxylic acids and Quinone's via oxidation reactions [54]. Oxidation occurs by singlet oxygen, organic peroxides, hydrogen peroxide, alkoxy radicals, peroxy radicals and hydroxyl radicals produced by UV irradiation directly or by oxides of iron and manganese or by photochemical process [55]. Manariotis et al., [56] have reported degradation of PAHs by the high frequency of ultrasound. Qiu et al., [57] during their studies found that PAHs can be removed from the soils by soil washing using sodium dodecyl sulfate (SDS) as the surfactant. Sodium dodecyl sulfate at the concentration of $20 \mathrm{~g} / \mathrm{L}$ can remove $37-44 \%$ of PAHs.

\subsubsection{Biological degradation}

Microorganisms mainly bacteria (Gordonia, Aeromicrobium, Dietzia, Mucobacterium, Arthrobacter, Bacillus) [58] and fungi degrade aerobically and anaerobically the PAHs into other smaller organic compounds with the end product carbon dioxide, water [59]. Bacterial degradation of the PAHs begins with the formation of cis-dihydrodiol by the attack of dioxygenase on the benzene ring, which in turn are converted into an intermediate catechol from which ring cleavage occurs. Thus, bacteria use the PAHs as carbon and energy source. Fungi convert PAHs into more watersoluble phenolic compounds and trans-dihydrodiols via the cytochrome enzyme P-450. 


\subsubsection{Photolytic degradation}

Photolysis degradation of PAHs occurs when the PAHs excites the electron within the molecule by the absorption of light. Photolysis degradation of PAHs is more effective in vapour phase or in aqueous solution. Low molecularweight PAHs and linear molecules are most degraded by this process [60].

\section{Conclusion}

Persistent organic compounds which are natural and anthropogenic contaminants are present in surface water, agricultural soils, and marine sediments, in foods, bovine and mother's milk. Some of POPs are carcinogenic; few are mutagenic to microbes and humans. Daily exposures to POPs are associated with respiratory problems in children and asthma. The maximum emission of PAHs and polychlorinated biphenyls especially of DDT is in the developing countries like China, India. Because of strong bonding in between POPs and particulate matter sediments act as reservoirs or sinks of POPs. The concentration of the PAHs in the agricultural soils and sediments globally ranges from $1 \mathrm{mg} / \mathrm{kg}$ to $300 \mathrm{~g} / \mathrm{kg}$ (based on the dry weight). These organic compounds POPs can be degraded by the microbes' algae, bacteria, and fungi. Maize (Zea mays L.) and sunflower (Helianthus annuus) acts as hyper accumulators for POPs. POPs can also be removed from the environment by dry deposition, and wet deposition, and chemical and photolytic degradation processes.

\section{Compliance with ethical standards}

\section{Acknowledgments}

The author thanks Dr. Sonal Bansal for her valuable suggestions.

\section{Disclosure of conflict of interest}

None

\section{References}

[1] Wang L, Xu X and Lu X. (2016). Composition, source and potential risk of polycyclic hydrocarbons (PAHs) in vegetable soils from the suburbs of Xianyang, Northwest China: a case Study. Environmental Earth sciences, 75 , 1-13.

[2] Odabasi M, Dumanoglu Y, Kara M, Altiok H, Elbir T and Bayram A.(2016). Spatial variations of PAHs and PCBs in Coastal air, seawater and sediments in a heavily industrialized region. Organohalogen Compounds, 78, 592-593.

[3] Umweltbundesamt (Hrsg). (2016). In Polycyclic Aromatic Hydrocarbons Harmful to the Environment! Toxic! Inevitable? Dr. Marc Brandt, Doreen Einhenkel-Arle (Eds.) Publisher: German Environment Agency Section IV 2.3 PO Box 140606813 Dessau-Roßlau January 2016.

[4] Schuhmacher M, Mari M, Nadal M and Domingo JL. (2019). Concentrations of dioxins and furans in breast milk of women living near a hazardous waste incinerator in Catalonia, Spain. Environment International, 125, 334341.

[5] Brajenović N, Karačonji IB and Jurič A. (2018). Levels of polychlorinated biphenyls in human milk samples in European countries. Archives Industrial Hygiene Toxicology, 69, 135-153.

[6] Bansal V and Kim Ki-Hyun. (2015). Review of PAH contamination in food products and their health hazards. Environment International, 84, 26-38.

[7] World Health Organization (WHO). (2007). The use of DDT in malaria vector control. WHO Position Statement, 2011 World Health Organization 20. Avenue Appia - CH-1211 Geneva 27 infogmp@who.int.

[8] Van den Berg H. (2009). Global status of DDT and its alternatives for use in vector control to prevent disease. Environmental Health Perspective, 117, 1656-1663.

[9] IPCS (International Programme on Chemical Safety) (2010). Polycyclic aromatic hydrocarbons, selected non heterocyclic.

[10] Unwin J, Cocker J, Scobbie E and Chambers H. (2006). An assessment of occupational exposure to polycyclic aromatic hydrocarbons in the UK. Annual Occupational Hygiene, 50, 395-403. 
[11] Adenijj O, Okoh 00 and Okoh AI. (2019). Levels of Polycyclic Aromatic Hydrocarbons in the Water and Sediment of Buffalo River Estuary, South Africa and Their Health Risk Assessment.

[12] Cachada A, Da Silva EF, Durate AC and Pereira R. (2016). Risk assessment of urban soils contamination: The particular case of polycyclic aromatic hydrocarbons. Science of the Total Environment, 551-552, 271-284.

[13] Igwe JC and Ukaogo PO. (2015). Environmental Effects of Polycyclic Aromatic Hydrocarbons. Journal of Natural Sciences 5, 117-132.

[14] Gao P, da Silva E, Hou L, Denslow ND, Xiang P and Ma LQ. (2018). Human exposure to polycyclic aromatic hydrocarbons: Metabolics perspective. Environment International, 119, 466-477.

[15] Thompson LA, Ikenaka Y, Yohannes YB, van Vuren JJ,Wepener V and Smit J. (2017) . Concentrations and human health risk assessment of DDT from KwaZulu-Natal South Africa. Food Additives \& Contaminants: Part A, 34, 1959-1969.

[16] Cohn BA, La Merrill M, Krigbaum NY, Yeh G, Park JS, Zimmermann L and Cirillo PM. (2015). DDT Exposure in Utero and Breast Cancer. The Journal of Clinical Endocrinology \& Metabolism, 100, 2865-2872.

[17] Mladenovi'c M, Arsi'c BB, Stankovi'c N, Nezrina Mihovi'c N, Ragno R, Regan A, Mili'cevi'c JS, Trti'c-Petrovi'c TM and Mici'c R. (2018). The Targeted Pesticides as Acetylcholinesterase Inhibitors: Comprehensive CrossOrganism Molecular Modelling Studies Performed to Anticipate the Pharmacology of Harmfulness to Humans In Vitro. Molecules, 23, 2192-2203.

[18] Pongpiachan S, Hattayanone M and Cao J. (2017). Effect of agricultural waste burning season on PM2.5-bound polycyclic aromatic hydrocarbon (PAH) levels in Northern Thailand. Atmospheric Pollution Research, xxx, 1-12, 1309-1042.

[19] Wang X, Thai PK, Li Y, Li Q, Wainright W, Hawker DW and Muller JF. (2016). Changes in atmospheric concentrations of Polycyclic hydrocarbons and polychlorinated biphenyls between the 1990 and 2010 in an Australian city and the role of bushfires as a source. Environmental Pollution, 213, 223-231.

[20] Kong S, Li X, Li L, Yin Y, Chen K, Yuan L, Zhang Y, Shan Y and Ji Y. (2015). Variation of polycyclic aromatic hydrocarbons in atmospheric PM 2.5 during winter haze period around 2014 Chinese Spring Festival at Nanjing: Insights of source changes, air mass direction and firework particle injection. Science of the Total Environment, 520, 59-72.

[21] Choi SD. (2014). Time trends in the levels and patterns of polycyclic aromatic hydrocarbons (PAHs) in pine bark, litter, and soil after a forest fire. Science Total Environment, 470,1441-1449.

[22] Caruso JA, Zhang K, Schroeck NJ, McCoy B and McElmurry B. (2015). Petroleum Coke in the urban environment: A review of potential health effects. International Journal of Environmental Research and Public Health, 12, 6218-6231.

[23] Singh DK and Gupta T. (2016). Effect through inhalation on human health of PM1 bound polycyclic aromatic hydrocarbons collected from foggy days in northern part of India. Journal of Hazardous Materials, 306, 257268.

[24] Pham CT, Tang N, Toriba A and Hayakawa, K. (2015). Polycyclic Aromatic Hydrocarbons and Nitropolycyclic Aromatic Hydrocarbons in Atmospheric Particles and Soil at a Traffic Site in Hanoi, Vietnam. Polycyclic Aromatic Compounds, 35, 355-371.

[25] Orecchio S, Amorello D, Barreca S and Valenti, A. (2016). Wood pellets for home heating can be considered environmentally friendly fuels? Polycyclic aromatic hydrocarbons (PAHs) in their ashes. Microchemical Journal, 124, 267-271.

[26] Luo W, Gao J, Bi X, Xu L, Guo J, Zhang Q and Kang S. (2016). Identification of sources of polycyclic aromatic hydrocarbons based on concentrations in soils from two sides of the Himalayas between China and Nepal. Environmental Pollution, 212, 424-432.

[27] Wang C, Dao X, Zhang LL, Lv YB and Teng EJ. (2015). Characteristics and toxicity assessment of airborne particulate polycyclic aromatic hydrocarbons of four background sites in China: Zhongguo Huanjing Kexue/China. Environmental Science, 35, 3543-3549.

[28] Li PH, Wang Y, Li YH, Li HL and Yi X. (2015). Origin and Distribution of PAHs in Ambient Particulate Samples at High Mountain Region in Southern China. Advances in Meteorology. 15,245438. 
[29] Shen G, Zhang Y, Wei S, Chen Y, Yang C, Lin P and Tao S. (2014). Indoor/outdoor pollution level and personal inhalation exposure of polycyclic aromatic hydrocarbons through biomass fuelled cooking. Air quality. Atmosphere \& Health, 7, 449-458.

[30] Jiang YF, Yves UJ, Sun H, Hu XF, Zhan HY and Wu YQ. (2016). Distribution, compositional pattern and sources of polycyclic aromatic hydrocarbons in urban soils of an industrial city, Lanzhou, China. Ecotoxicological Environmental Safety, 126,154-162.

[31] Karyab H, Yunesian M, Nasseri S, Mahvi A.H, Ahmadkhaniha R., Rastkari N and Nabizadeh R. (2013). Polycyclic Aromatic Hydrocarbons in drinking water of Tehran. Journal Environmental Health Science Engineering, 11, 25-37.

[32] Edokpayi JN, Odiyo JO, Popoola OE and Msagati TAM. (2016). Determination and Distribution of Polycyclic Aromatic Hydrocarbons in Rivers, Sediments and Wastewater Effluents in Vhembe District, South Africa. International Journal Environmental Research Public Health, 13, 387-394.

[33] Tzoraki O, Karaouzas I, Patrolecco L, Skoulikidis N and Nikolaidis NP. (2015). Polycyclic aromatic hydrocarbons (PAHs) and heavy metal occurrence in bed sediments of a temporary river. Water Air Soil Pollution, 226, 421430.

[34] Malik A, Verma P, Singh AK and Singh KP. (2011). Distribution of polycyclic aromatic hydrocarbons in water and bed sediments of the Gomti River, India. Environmental Monitoring Assessment, 172, 529-545.

[35] Aly-Salem DMS, Abou-Elmagd F, Morsy M, El Nemr A, El-Sikaily A and Khaled A. (2014). The monitoring and risk assessment of aliphatic and aromatic hydrocarbons in sediments of the Red Sea, Egypt. The Egyptian Journal of Aquatic Research, 40, 333-348.

[36] Maliszewska-Kordybach B, Smreczak B and Klimkowicz-Pawlas A. (2009). Concentrations, sources, and spatial distribution of individual polycyclic aromatic hydrocarbons (PAHs) in agricultural soils in the Eastern part of the EU: Poland as a case study. Science of the Total Environment, 407, 3746-3753.

[37] Kumar V, Kothiyal N and Saruchi. (2016). Analysis of Polycyclic Aromatic Hydrocarbon, Toxic Equivalency Factor and Related Carcinogenic Potencies in Roadside Soil within a Developing City of Northern India. Polycyclic Aromatic Compounds, 36, 50-526.

[38] Bortey-Sam N, Ikenaka Y, Nakayama SMM, Akoto O, Yohannes YB, Baidoo E, Mizukawa H and Ishizuka M. (2014).Occurrence, distribution, sources and toxic potential of polycyclic aromatic hydrocarbons (PAHs) in surface soils from the Kumasi Metropolis, Ghana. Science Total Environment, 496,471-478.

[39] Bi X, Luo W, Gao J, Xu L, Guo J, Zhang Q, Romesh KY, Giesy JP, Kang S and de Boer J. (2016). Polycyclic aromatic hydrocarbons in soils from the Central-Himalaya region: Distribution, sources, and risks to humans and wildlife. Science of the Total Environment, 556, 12-22.

[40] Wang L, Zhang S, Wang L, Zhang W, Shi X, Lu X and Li X. (2018). Concentration and Risk Evaluation of Polycyclic Aromatic Hydrocarbons in Urban Soil in the Typical Semi-Arid City of Xi'an in Northwest China. International Journal of Environmental Research and Public Health, 15(4), 607-618.

[41] Zhao L, Dong YH and Wang H. (2013). Residues of organochlorine pesticides and polycyclic aromatic hydrocarbons in farm-raised livestock feeds and manures in Jiangsu, China. The Science of the Total Environment, 450-451, 348-355.

[42] Mohamed GG, Souaya ER, Khalil, LH, Rawash El-Shaimaa A, El-Shaimaa GA and El-Gammal MH. (2018). Distribution and Health Hazards of Polycyclic Aromatic Hydrocarbons in Egyptian Milk and Dairy-Based Products. Beverages, 4, 63-72.

[43] Grung M, Lin Y, Zhang H, Steen A, Huang J, Zhang G and Larssen T. (2015). Pesticide levels and environmental risks in aquatic environments in China, A review. Environment International, 81, 87-97.

[44] Ogbeide 0, Tongo I and Ezemonye L. (2015). Risk assessment of agricultural pesticides in water, sediment, and fish from Owan River, Edo state, Nigeria. Environmental Monitoring and Assessment, 187, 654-666.

[45] Yadav IC, Devi NL, Syed JH, Cheng Z, Li J, Zhang G and Jones KC. (2015). Current status of persistent organic pesticides residues in air, water, and soil, and their possible effect on neighbouring countries: a comprehensive review of India. Science of the Total Environment, 511, 123-137. 
[46] Mamta Rao RJ and Wani KA. (2015). Concentration of organochlorine and organophosphorus pesticides in different molluscs from Tighra reservoir, Gwalior, India. Bulletin of Environmental Contamination and Toxicology, 95, 332-339.

[47] Barhoumi B, Lemenach K, Dévier MH, El Megdiche Y, Hammami B, Ben Ameur W, Hassine SB, Cachot J, Budzinski $H$ and Driss MR. (2014). Distribution and ecological risk of polychlorinated 625 biphenyls (PCBs) and organochlorine pesticides (OCPs) in surface sediments from the Bizerte lagoon, Tunisia. Environmental science and pollution research international, 21, 6290-6302.

[48] Abdel-Shafy HI and Mansour MSM. (2016). A review on polycyclic aromatic hydrocarbons: Source, environmental impact, effect on human health and remediation. .Egyptian Journal of Petroleum, 25, 107-123.

[49] Zhong Y and Zhu L. (2013). Distribution, input pathway and soil-air exchange of polycyclic aromatic hydrocarbons in Banshan Industry Park, China. Science of the Total Environment, 444, 177-182.

[50] Bozlaker A, Odabasi M and Muezzinoglu A. (2008). Dry deposition and soil-air gas exchange of polychlorinated biphenyls (PCBs) in an industrial area. Environmental Pollution, 156, 784-793.

[51] Wang Y, Li Peng-hui, Li Hong-li, Liu Xiao-huan and Wang Wen-xing. (2010). PAHs distribution in precipitation at Mount Taishan: China, Identification of sources and meteorological influences. Atmospheric Research, 95, 17.

[52] Wu X, Fan Z, Zhu X, HwaJung K, Ohman-Strickland P, Weisel CP and Lioy PJ. (2012). Exposures to volatile organic compounds (VOCs) and associated health risks of socio-economically disadvantaged population in a "hot spot" in Camden, New Jersey. Atmospheric Environment, 57, 72-79.

[53] Kacálková L and Tlustoš P. (2011). The uptake of persistent organic pollutants by plants. Central European Journal of Biology, 6(2), 223-235.

[54] Rivas J, Beltran FJ and Acedo B. (2000). Chemical and photochemical degradation of acenaphthylene: Intermediate identification. Journal of Hazardous Materials, 75(1), 89-98.

[55] Hassan SSM, El Azab WIM, Ali HR and Mansour MSM. (2015). In: The 18th International conference on petroleum, mineral resources and development. EPRI, Cairo, Egypt, 8-10.

[56] Manariotis ID, Karapanagioti HK and Chrysikopoulos CV. (2011). Degradation of PAHs by high frequency ultrasound. Water Research, 45, 2587-2594.

[57] Qiu Y, Xu M, Sun Z and Li H. (2019). Remediation of PAH-Contaminated Soil by Combining Surfactant Enhanced Soil Washing and Iron-Activated Persulfate Oxidation Process. International Journal Environmental Research Public Health, 16, 441-448.

[58] Nikitha T, Satyaprakash M, Satya Vani S, Sadhana B and Padal SB. (2017). A Review on Polycyclic Aromatic Hydrocarbons: Their Transport, Fate and Biodegradation in the Environment. International Journal Current Microbiology Applied Science, 6(4), 1627-1639.

[59] Haritash AK and Kaushik CP. (2009). Biodegradation aspects of polycyclic aromatic hydrocarbons (PAHs): a review. Journal of Hazardous Materials, 169(1-3), 1-15.

[60] Niu X, Ho SSH, Ho KF, Huang Y, Sun J, Wang Q and Cao J. (2017). Atmospheric levels and cytotoxicity of polycyclic aromatic hydrocarbons and oxygenated PAHs in PM 2.5 in the Beijing-Tianjin-Hebei region. Environmental Pollution, 231, 1075-1084.

\section{How to cite this article}

Bansal OP. (2019). Persistent organic compounds in the environment their impact on human health: A review. GSC Biological and Pharmaceutical Sciences, 8(2), 81-88. 